\title{
Dionisiese spore in Kusa se metafisika
}

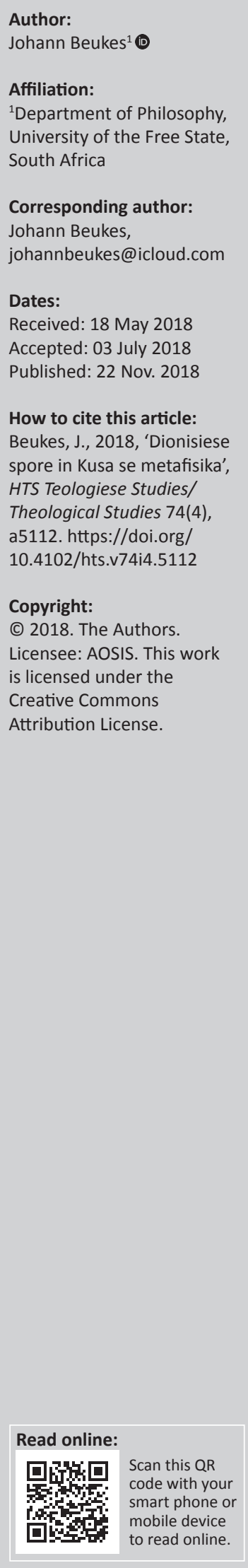

This article investigates the palimpsest reception of Pseudo-Dionysius (ca. 500) in the metaphysics of Nicholas of Cusa (1401-1464). The article covers Cusa's political theory and metaphysics, which are intertwined. Reading Cusa against the backdrop of an analysis of Pseudo-Dionysius' metaphysics in a preceding article, the author, in a synthetic conclusion, isolates seven Dionysic 'trails' (S1 to S7) in Cusa's metaphysics: the interpretation of transcendence as bound to immanence; the affirmation of God's transcendence in the world (or a metaphysics of 'creation as teophany'); the radical transcendence and simultaneous radical immanence of God (that is, God as 'Beingness'); fundamental restrictions of language and the analogical 'Naming' of God; creation as a system of dialectical symbols about God; the analogical participation of the subject in creation; and unification (reditus, the 'flowing of things back to God'). The Dionysic trails in Cusa's metaphysics are described as a noteworthy, if not important, palimpsest in the corpus of late Medieval philosophy and is indicative of what the author puts forward as 'discursive memory', which is presented as a modern-critical concept.

\section{Inleiding}

Hierdie artikel, in opvolging van 'n voorafgaande ondersoek (Beukes 2018), verken 'n merkwaardige palimpses ${ }^{1}$ vanuit die eerste helfte van die vyftiende eeu, naamlik die nawerking van Pseudo-Dionisius (ca. 500) as skugter informerend tot die metafisika van Nikolaus van Kusa (1401-1464). Die voorafgaande ondersoek het aandag geskenk aan Dionisius se eie resepsie van metafisika vanuit die erfenisse van Middel-Platonisme en Neoplatonisme. Daarna is Dionisius se unieke metafisika oopgedek en tendensieuse, idiosinkratiese temas in sy metafisika uitgewys. In hierdie opvolgartikel word Kusa se politieke teorie en metafisika, wat onlosmaaklik met mekaar verweef is, bespreek. Die laaste afdeling van die artikel bring Dionisius en Kusa in sagte of tematiese jukstaposisie met mekaar.

Sewe 'spore' word in Kusa se metafisika uitgelig, wat hoogs waarskynlik, moontlik ongetwyfeld, Dionisies in oorsprong is: die verstaan van transendensie as verknoop met immanensie; die bevestiging van God se transendensie in die wêreld ('skepping as teofanie'); die radikale transendensie en tegelyk radikale immanensie van God ('God as Synheid'); taalbeperktheid en die onvermydelikheid van die analogiese 'be-Naming' van God; skepping as 'n stelsel van dialektiese simbole oor God; die analogiese deelname van die subjek aan die werklikheid; en 'eenwording' of reditus, 'n begrip wat tematies kenmerkend aan beide Dionisius en Kusa se metafisika is, naamlik dat alle dinge 'terugvloei na God'.

Die palimpses wat vanuit hierdie twee artikels aangetoon word, word as merkwaardig getipeer, en vanuit 'n modern-kritiese gesigspunt ten opsigte van die herwinning of rehabilitering van dit wat vergete of verlore geraak het (Beukes 2005), as 'n belangrike voorbeeld of selfs geleier van 'diskursiewe herinnering' aangebied.

\section{Kusa se politieke teorie en metafisika}

Baie ver, trouens meer as $900^{2}$ jaar die Middeleeuse weg af, verskyn talle metafisiese temas en konsepte wat latent na Dionisius terugkoppel, in die werk van Nikolaus van Kusa. Inderdaad is Kusa (1401-1464) die 'laaste Middeleeuse en eerste Renaissance filosoof' (Beukes 2012:15), of dalk tog die 'poortwag van die moderne' (Dupre en Hudson 2006:466). In beide hierdie lesings

\footnotetext{
1.Die doel van beide artikels is om hierdie palimpses logies en sistematies te ondersoek. Die aard van hierdie artikel is enersyds oorsigtelik, in die sin dat grondig aandag gegee word aan die relevante intellektuele geskiedenis. Die artikel is andersyds analities en sinteties, bedoelende dat die primêre tekste so selfstandig moontlik gelees word sonder sekondêre teksbegeleiding, waarna die sekondêre tekste geraadpleeg en getoets word aan die outeur se lesing, om tot ' $n$ koherente sintese te kom. Die sewe Dionisiese 'spore' is die tekste geraadpleeg en getoets word aan die outeur se lesing, om tot ' $n$ koherente sintese te kom. Die sewe Dionisiese 'spore' is die einde suggestie dat Kusa se 'terugblik' na of 'rehabilitasie' van Dionisius vir laat-moderniteit self betekenisvol behoort te wees, in die einde suggestie dat Kusa se 'terugblik' na of 'rehabilitasie' van Dionisius vir laat-moderniteit self betekenisvol behoort te wees, in die
sin dat dit wat skynbaar verlore of vergete geraak het, ' $n$ eietydse en weliswaar verarmde konteks van nuwe impetus kan voorsien.

2.Let daarop dat syfers van een tot nege uitgeskryf word en vanaf 10 konsekwent per Arabiese syfer aangedui word.
} 
word Kusa as die wesenlike en enigmatiese skarnierfiguur tussen die Middeleeue en die vroeg-moderne aangebied. In $\mathrm{Kusa}^{3}$ se werk kulmineer talle van die temas wat in terme van oorsprong deur die outeur elders (Beukes 2012:15-19) as kenmerkend van 'n 'post-skolastiese' bedding aangedui is: die skeiding tussen kerk en staat, waaruit sekularisme gespruit het, die skeiding tussen teologie en filosofie, waaruit die verselfstandiging van die natuurwetenskappe gespruit het, skolasties-afstandelike institusiekritiek, sosiaal-transformerende pragmatiek en materialisme. By hierdie post-skolastiese motiewe verdien ook Kusa se metafisika, in die sonderlinge dialekties-mistieke uniekheid daarvan, 'n plek.

Kusa deel die post-skolastiese kritiek van die universiteitskolastiek en die afstandname van filosofie as institusionele aktiwiteit. Hy transendeer skoolgebondenheid volledig en is so min Skotiaans as wat hy Ockhamiaans is. Hy is lank nie meer ' $n$ tipiese skolastikus wat met die gebruik van tegniese jargon quaestiones of 'n quodlibet skryf en die tradisie daarmee kommentarieer nie. In 'n styl wat herinner aan Anselmus van Kantelberg eeue voor hom, skryf Kusa kort monografiese werke waarin hy 'n dialektiesspekulatiewe mistiek ${ }^{4}$ ontwikkel. Dit blyk nie so duidelik uit sy politieke teorie nie, wat hy van Padua erf (Beukes 2012: 6-8), maar wel uit sy metafisika. Omdat sy politieke teorie egter die Kuseaanse nosie van 'konkordansie' ontwikkel, wat sentraal staan tot sy metafisika, word beide Kusa se politieke teorie en sy metafisika vervolgens bespreek, voordat oorbeweeg word na 'n jukstaposisie van Dionisius en Kusa in terme van 'n oorvleuelende metafisika.

$\mathrm{Na}$ 'n kort inleidingstudie aan die Universiteit van Heidelberg in 1416, studeer Kusa regte vanaf 1417 tot 1423 aan die Universiteit van Padua, waar hy ook in 1424 in die regsgeleerdheid promoveer. In 1425 sluit hy by die Universiteit van Keulen aan waar hy publiekreg doseer, maar ook filosofie en teologie begin studeer. In 1432 word hy afgevaardig na die konsilie van Basel, waar twee belangrike sake hanteer is: (1) die reeds verketterde (by die konsilie van Konstans [1414-1418]), leerstellinge van Johannes Hus en die gevolglike pogings tot kerkhervorming en die aktivering van nasionalisme in Bohemië deur Hus-lojaliste, en (2) in die nagloed van Wyclif se institusiekritiek (Beukes 2012:9-12), die vraag na kerklike en in besonder pouslike soewereiniteit. Kusa word in 1448 'n kardinaal van die kerk en sterf in 1464 in Rome. ${ }^{5}$

Ten tye van die konsilie van Basel in 1433, skryf Kusa sy 'Katolieke Konkordansie' (De concordantia catholica), waarin

3. Hierdie bespreking oor Kusa is gebaseer op ' $n$ analise en sintese van die gelysde primêre tekste (Kusa 1932-2007, 1981, 1983, 1985, 1991), asook die volgende sekondêre tekste: Hopkins se inleiding (1978) asook sy vertalings, redigerings en kommentare van die primêre Kusa-tekste is gesaghebbend in die navorsin (Kusa 1981, 1983, 1985); daarby is verwerk Albertson (2008:61-81, 2010:471-85); Beierwaltes (1977, 1985, 1997); Casarella (2008:667-78); Copleston (1972:317-20); Duclow (2002:71-87); Dupre en Hudson (2006:466-74); Luscombe (2004:173-7); Sigmund (1963:1-25) en Wyller (1970:419-43).

4.Naas sy afhanklikheid van Padua (sien voetnota 6 infra ten opsigte van politieke filosofie), was Kusa veel dank verskuldig aan Johannes (Meister) Eckhardt (ca.12601328) ten opsigte van die spekulatief-mistiese kwaliteit van sy metafisiese dialektiek.

5.Hopkins (1978) staan uit as onmisbaar in die Kusa-navorsing. Flasch (1966) se Kusamonografie (Duits en betreklik gedateerd) kan egter ook sterk aanbeveel word, veral in terme van die relevante gedeeltes oor Kusa se metafisika.

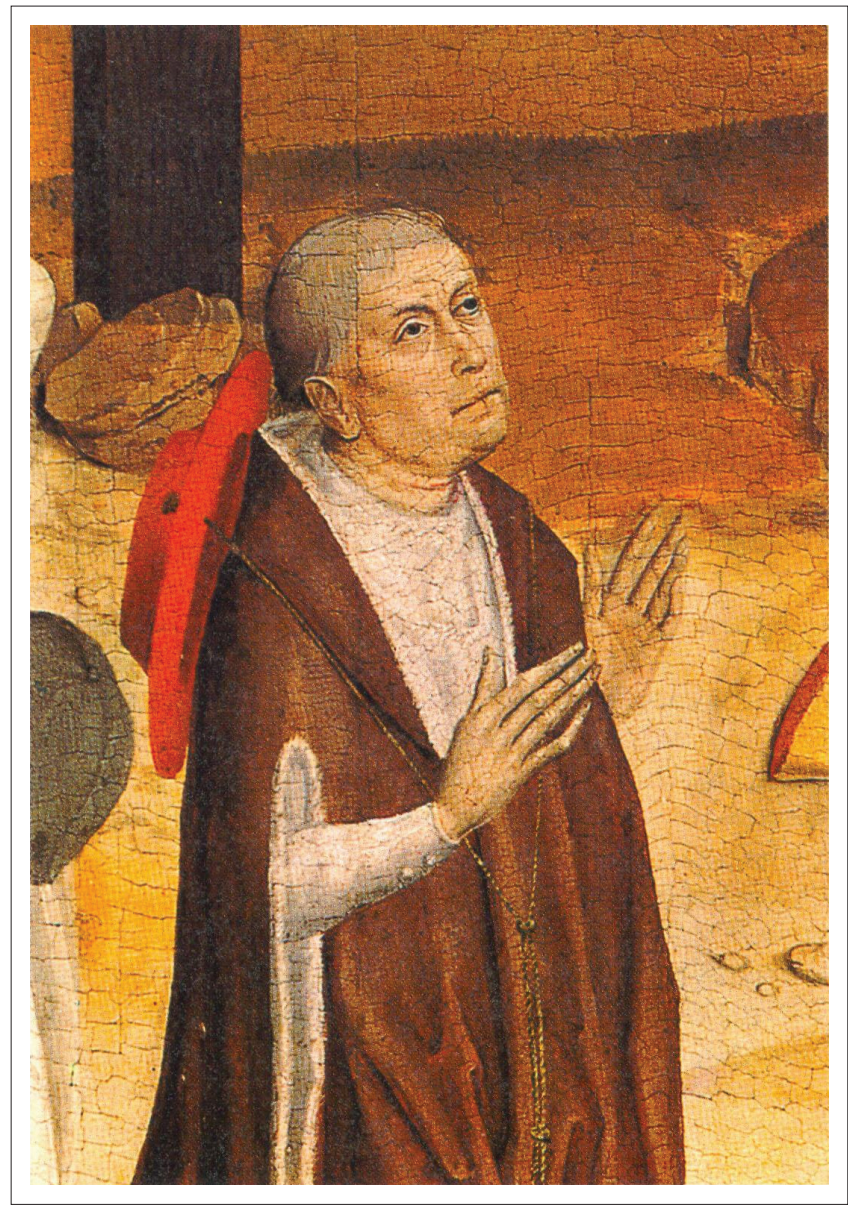

Bron: Anoniem, n.d., Nicolaus Cusanus, Meister des Marienlebens, ca.1463-ca.1490, viewed n.d., from https://de.wikipedia.org/wiki/Datei:Nicholas_of_Cusa.jpg

FIGUUR 1: Nicolaus Cusanus, Meister des Marienlebens, ca.1463-ca.1490.

hy homself ten opsigte van beide sake op die konsilie se agenda posisioneer. Kusa bepleit die opheffing van pouslike soewereiniteit ten gunste van 'n konsiliegebaseerde besluitnemingsproses (Flasch 1966:32), wat wesenlik aankom op'n demokratisering van die kerklike besluitnemingsproses. Daar moet in die kerk geleentheid tot debat wees en die beginsel van instemming of consentia moet in hierdie proses sentraal staan (Kusa 1991:76). Besluitneming in die kerk word nie op die pouslike diskresie gegrond nie, maar op die afgevaardigdes na die konsilie se geleentheid tot instemming of nie-instemming, oor enige saak rakende die formulering van belydenis en beleid.

Kusa is in die werk duidelik baie aan Padua se Defensor Pacis van 1324 verskuldig (Beukes 2012:7; Flasch 1966:28): Padua se pleidooi vir die onherroeplike skeiding van die aardse en die geestelike, dus ook van kerk en staat, met daarby die 'enkele soewereiniteit' wat op die aarde - naamlik in die staat, die civitas - self gevind moet word, word in terme van die dinamika van die civitas deur Kusa heropgeneem en kerklik toegepas - afgesien daarvan dat Padua self 'n voorstaander van konsiliebesluitneming as sodanig was. ${ }^{6}$

6.Marsilius van Padua (1280-1343) is gebore uit ' $n$ vooraanstaande familie en het hom, na die afhandeling van sy studies in die geneeskunde en regsgeleerdheid, volledig tot die filosofie gewend. Hy het op ' $n$ jong ouderdom rektor van die volledig tot die filosofie gewend. Hy het op ' $n$ jong ouderdom rektor van die
Universiteit van Parys geword, juis omdat sy studieloopbaan die volledige interfakulteit-kurrikulum aan Parys ondervang het. Hy was ook buite Rome en Parys, 
Volgens Kusa (1991:90) moet kerk en staat nie bloot van mekaar geskei word nie. In die kerk self moet die enkele soewereiniteit van die civitas neerslag vind. Dit dui op ' $n$ konformering van die kerk aan die dinamika van die civitas. Daarom word De concordantia catholica 'n werk met politiek-filosofiese betekenis. Kusa (1991:80) maak eklektiespragmaties ${ }^{7}$ gebruik van beginsels van die administratiefreg,

\section{(voetnoot 6 vervolg...)}

veral in Oxford, 'n diep gerespekteerde akademiese figuur (vgl. Gewirth 1979:26) Padua speel in op 'n politiek-teoretiese diskoers wat in die 1320's reeds bykans ' $n$ van die via moderna, soos kenteoreties reeds by Ockham gevestig. Keiser Frederik II (d.1250) het probeer om die keiserlike outonomie teen pouslike intervensie te (d.1250) het probeer om die keiserlike outonomie teen pouslike intervensie te outoriteite', te wete keiserlike en pouslike outoriteit (vgl. Bertelloni 2006:413). Die outoriteite', te wete keiserlike en pouslike outoriteit (vgl. Bertelloni 2006:413). Die
keiserryk is hiervolgens volledig onafhanklik en ontleen outoriteit nie aan die pous nie, maar regstreeks aan God, a Deo culmen imperii obtinemus. Sowel keiserlike as pouslike outoriteit geniet toepassing in hulle eie onderskeibare domeine en die een kan nie aan die ander ondergeskik gestel word nie. Elkeen word in die vervulling van 'verskillende wesenlike funksies' (se ad invicem complectuntur) deur die ande aangevul (vgl. Gewirth 1979:32). Gelyklopend met hierdie teoretiese posisie van Frederik II ontwikkel daar ook in die eerste helfte van die dertiende eeu, in die middel-skolastiek, radikaal nuwe rigtings in die politieke filosofie. Dit is gestu deu die uiteindelike herwinning van Aristoteles se volledig oorlewende korpus in die filosofiese etiek en die politieke teorie gedurende die middel-skolastiek die toenemente institusionele konsolidering gedurende toenemende instituswese in Wes-Europ vanaf die laat $13 \mathrm{e}$ eeu en, as logiese konsekwensie van beide voorgenoemde, verhoogde uitsette in logika en sistematiese teorie (vgl. Gewirth 1979:28). Daarom verskyn daar sedet Aquinas se gevierde De regimine principum ' $n$ hele aanta politiek-teoretiese werke wat hierdie teorie oor twee outoriteite beredeneer en vanuit verskillende premisses probeer bestendig: die indirekte of ontleend subordinasie van die aardse aan die geestelike (Aquinas), die direkte subordinasie van die aardse aan die geestelike en die bedoelde reduksie van die aardse (bv. Gilius van Rome), betreklike wedersydse onafhanklikheid (bv. Johannes van Parys) en absolute wedersydse onafhanklikheid (bv. Dante Alighieri; vgl. Bertelloni 2006:413). Uit hierdie onderskeibare teoretiese posisies kristalliseer nietemin ' $n$ enkele teoretiese model van twee mede-aktiewe kragte - eenvoudig gestel, twee soewereiniteite (wat later in die Reformasie as ' $n$ wesenlike posisionering herwin sou word, veral by Luther; vgl. Munz [1960:156]). Dit is die teoretiese model wat Padua van sy politiek-teoretiese voorgangers vanuit die lat dertiende eeu erf (Munz 1960:170) Padua se posisie was institusie-krities veel mu 1960:170). Padu se posis ie steed sober posisie van Ockham, in die sin dat hy die pousdom as' $n$ verskynsel teengestaan het en nie soos Ockham bloot per ondersoek die dwalinge van Johannes XXII wo uitwys nie. Dit is juis die publikasie van Padua se teoretiese posisie in 1324 in sy Defensor Pacis, waar die opkoms van die via moderna en die afskeid van die laat skolastiek se steeds sobere vorm van proposisionele kritiekbeoefening, duidelik beklemtoon word. Padua (1932: III.iii) neem naamlik onherroeplik afskeid van die bogenoemde dertiende-eeuse model van twee outoriteite. Hy argumenteer dat soewereiniteit enkel, eenvoudig, onverdeelbaar en onherleibaar is - en vernaamlik dat hierdie soewereiniteit nie in die pous nie, maar in die mensheid self vestig (legislator humanus) (Padua 1932: 1.xix.6; vgl. Bertelloni 2006:414). Defensor Pacis is ' $n$ breukteks - hierna verander alles wat nog pertinent Middeleeus aan die laatskolastiek is. Defensor Pacis word binne minder as tien jaar 'n standaardteks in die politieke filosofie van die laat-skolastiek en kondig trouens die einde van die skolastiek aan. Die pleidooi vir die onherroeplike skeiding van die aardse en die geestelike, dus ook van kerk en staat met allerbelangrik daarby die 'enkele soewereiniteit' wat op die aarde - namlik in die staat, die civitas - self gevind mel soewereiniteit wat op die aarde - naamlik in die staat, die civitas - self gevind moet word, vertistiek 'n sekularisasie wat as dwingend, dringend sou ' $n$ enorme invloed uitoefen pouslike intevensie in de reeds sekulaiserende Europa, van die vroeg tot midde veertiende eeu, en lei die onontkombare werklikheid van " $n$ radikale skeiding tussen kerk en staat in. Die endemiese wanorde, korrupsie en geweld in die Italiaanse sosiale landskap word deur Padua (1932:III.ii) as die gevolg van pouslike arrogansie en triviale politieke ambisies uitgewys (vgl. Munz 1960:159). Padua beweeg uiteindelik van die plaaslike probleme in Rome en die Italiaanse stadstate self na ' $n$ algemene teorievorming. Die staat is volgens Padua ' $n$ 'perfekte' gemeenskap, wat binne die eie sfeer selfstandig, sorg-onafhanklik en selfbestendigend is (vgl. Gewirth 1979:31). Daar is volgens Padua (1932:I.xix.6) net twee soorte regerings: die eerste, 'n regering deur die toestemming of verkiesing van die heerser se onderdane, en die tweede, 'n regering teen die wil van die onderdane. Slegs eersgenoemde is legitiem - en die tweede is' $n$ vorm van tirannie. Die wette van die staat ontleen die legitiem - en die tweede is $n$ vorm van tirannie. Die wette van die staat ontleen die legitimerende werking daarvan nie aan die wil van die heersers of direk van God nie, maar hulle word deur die onderdane self van outoriteit voorsien. Hier is ideologies gesproke ' $n$ duidelike verskuiwing vanaf die vertikale na die horisontale. Die taak va wetgewing, in Padua se raamwerk vanselfsprekend horisontaal, mag wel na verskei liggame en sub-instellings gedelegeer word, wat redelikerwys van staat tot staa mag verskil (Padua 1932:I. xix.6). Die prins is die uitvoerende hoof van die staat - die onderdane, wat Padua (1932:I. xix.12) ondenkbaar selfs net 20 jaar vantevore prontuit 'burgers van die staat' noem, moet die prins verkieslik self verkies, hoewe Padua ook vir ander vorme van burgerlike toestemming voorsiening maak. ' $n$ Onbevoegde of wisselvallige prins moet sonder meer deur wetgewing verwyder kan word (Munz 1960:163). Defensor Pacis was buitengewoon invloedryk vir 'n werk wat nog so diep in die skolastiek self gebore en geborge is. Dit dui egter ook ' $n$ pertinente verskuiwing na die seculum aan in die poging om aan ' $n$ dualistiese oplossing te ontkom en die klassieke opvatting van civitas as'n enkele soewereiniteit wat in die staat self vestig te herwin. Geen verteenwoordiger vanuit die Vatikaan was in staat om die werk teoreties effektief of langblywend te ondermyn nie. Dit het was in steat on die we sowel eertyds-ortodokse Katolieke en die veertiende-eeuse proto-Hervormers van ingre in die opente politieke filosofie en metafisika uitgeoefen. verwys hoogs eklekties na die 'beginsels' van instemming en verteenwoordiging by konsilies in die laat-patristiek, en bied op grond van beide talle voorstelle vir die hervorming van die kerk aan.

Presies dieselfde beginsels behoort egter, volgens Kusa (1991:84), vir keiserlike diskresie en soewereiniteit te geld: Dit is nie net die kerk wat aan die hand van die beginsels van instemming en verteenwoordiging hervorm behoort te word nie, maar die staat self. Instemming is in sowel die kerk as die staat ' $n$ voorwaarde vir die legitimiteit van die wet en die regering. Kusa doen weer eklekties (omdat die Dietse [Romeins-Hollandse] reg op hierdie stadium reeds gevestig is) 'n beroep op die outoriteit van die Romeinse publiekreg en privaatreg as geanker in die rede dat geldige wetgewing op die natuurlike reg gegrond is en alle natuurlike reg is in die rede gegrond (Kusa 1991:98). Daarom is die wet - die objektiewe reg en die subjektiewe regte wat daaruit voortvloei - intrinsiek in die menslike rede gevestig; nie in die transendente nie (Flasch 1966:45).

Soos Padua (Beukes 2012:6-8; ook eindnota 6) in Defensor Pacis, onderskryf Kusa (1991:206-11) die beginsel van 'die swaarder deel' of meerderheid, hetsy in kerklike konsilies waar die pous aartsbiskoppe en biskoppe ontmoet of in imperiale konsilies waar die keiser prinse en hertogte ontmoet. Die beginsel van verteenwoordiging is vir Kusa eenvoudig en eksplisiet: By 'n kerklike konsilie word die gelowiges - opvallend, vir Kusa ${ }^{8}$ reeds 'die kerk' - legitiem verteenwoordig deur publiek-kerklike ampsdraers soos kardinale, aartsbiskoppe en biskoppe, eerder as die pous. Deur provinsiale biskoppe in te sluit, word die kerk in staat gestel om breed te reflekteer oor 'die kerk' - met inagname dat 'die kerk' dan siklies verteenwoordig word deur 'die kerk', te wete gelowiges in die provinsies. Presies dieselfde behoort vir die staat te geld, wat Kusa uiteraard digby kiesafdelings en die weefsel van die moderne demokrasie bring.

Daarom kan Kusa (1991:128) dié absoluut merkwaardige (vir 'n voormoderne denker) uitspraak maak: 'Alle mag, hetsy geestelik, tydelik of liggaamlik, is potensieel in mense'. God is hiervan nie uitgesluit nie. Dialekties is dit God self wat die beginsel van verteenwoordiging verteenwoordig (Kusa 1991:194). Kusa (1991:195) beskryf hierdie posisie so sober moontlik as 'intermediërend': Mag kom van bo sowel as van onder - of miskien juis eerder, van-langs.

Daar is eenvoudig geen wyse waarop Kusa hierdie kerklike en politieke demokratiseringsposisie sonder die post-skolastiese bedding van sekularisering, institusie-kritiek en 'n eklektiese pragmatiek sou kon handhaaf nie. Daarsonder sou hy gewoon as ketter op die brandstapel tereggestel gewees het. Tye het egter in die 1440's inderdaad verander. Die tyd van skolastiese rapport was verby. Dit het tyd geword vir sonderlinge post-skolastiese betragting. Kusa, en sy lewe het letterlik daarvan afgehang, is daarom as die laaste 8.Soos Wyclif (1328-1384) voor hom (vgl. Beukes 2012:9-12). 
post-skolastikus alles aan die ontwikkelinge sedert Ockham se afsterwe in 1349 verskuldig. Kusa is nie bloot verduur nie, maar verwelkom. Die skolastiek het aanbeweeg.

Dit word selfs duideliker uit Kusa se metafisiese posisie. Kusa bepleit in sy metafisika bogenoemde 'intermediërende posisie' op weg na harmonie of konkordansie, hetsy tussen pous en konsilie, of tussen keiser en konsilie - en ten diepste, tussen God en mens. Kusa se diepe oortuiging van die katolieke konkordansie reflekteer sy vertroue in die rasionele harmonie van die heelal, 'n metafisika van Een (Flasch 1966:2), waarby ons pertinent vertoef infra. Daarom definieer Kusa reeds vroeg in De concordantia catholica 'harmonie' as 'voortvloeiend vanuit die Vredeskoning 'n oneindige konkordansie, 'n spirituele harmonie vir almal wat ondergeskik en tog gebonde is aan Hom' (Kusa 1991:5). Elke konkordansie bestaan volgens Kusa uit verskille, en hoe minder opposisie daar tussen die verskille is, hoe groter die konkordansie. Die hoogste konkordansie is tussen die Persone in die Drie-eenheid: die eenheid in drieheid en die drieheid in eenheid, wat God is (Kusa 1991:7).

Hierdie konkordansie presenteer vir Kusa dus die eerste beginsel, of God. Vanuit die eerste beginsel ontwikkel Kusa 'n metafisiese standpunt met 'n uniek dialekties-spekulatiefmistiese karakter. In De visione dei (1453), verken Kusa (1985:153) die visie wat God op God se skepsels het en die visie wat God se skepsels op God het. God het die 'een oog wat alles sien', sonder om die blik te verskuif. Mense daarenteen sien alleen waartoe die menslike oog gedraai is vanuit 'n begrensde hoek. Die eerste beginsel sien alles soos dit werklik is - dialekties gestel, die 'oorsaak van alle dinge sien alle dinge soos wat dit veroorsaak is' (Kusa 1985:149). God se oog is - onbedinkbaar - een, oneindige sfeer. Kusa (1985:153) verwys na die beroemde Christus-uitbeelding van sy tydgenoot, Rogier van der Weyden (1399-1464), waar Christus se gesig só geskets is dat dit voorkom of sy blik op elke kyker gerig word, ongeag die hoek vanwaar daar na die skildery gekyk word. Dit vergestalt coincidentia, [nie toeval nie, maar ko-insidensie] wat alleen in God effektief is, tussen gelyktydig sien en om-gesien-te-word.

In De li non aliud ('Oor die nie-ander', 1462) neem Kusa (1983:7-12) hierdie dialektiek verder deur te argumenteer dat God die aardse transendeer en tog terselfdertyd immanent daarin teenwoordig is - immanent in die sin dat God nie anders is as enige ding nie; transendent in die sin dat God ongekwalifiseerd nie-ander is. Kusa (1983:7) gebruik 'n analogie om te verduidelik: Lig is nie dieselfde as kleur nie, tog is die lig in kleur nie anders as die kleur nie. God kan sonder die heelal bestaan, net soos wat lig sonder kleur kan bestaan. Net soos wat kleur 'n modifikasie van lig is, kan die heelal egter as 'n modifikasie van God verstaan word. Kusa se oogmerk is om aan te toon dat God alle onderskeide wat mense kan maak, transendeer: God is anders as die heelal, maar, dialekties, in die heelal self is God 'nie-anders' as die heelal. God transendeer elke kategorie omdat God absoluut 'nie-ander' is (Kusa 1983:15). Toegepas op die triniteitsleer, argumenteer Kusa (1983:14) dat die Gees die connexio unitatis et aequalitatis, die unie van eenheid (die Vader) en gelykheid (die Seun) is. Eenheid, gelykheid en unie dui volgens Kusa (1983:15) die on-onderskeid van God self aan, die ongedifferensieerde aard van God se syn, en God se 'nieandersheid'.

Kusa se metafisika is wesenlik 'n reeks pogings om 'die gewone konseptuele beperkinge' te 'transendeer' (Kusa 1983:5). Gevolglik presenteer Kusa paradokse wat sowel boeiend vir sommige as afstootlik vir ander tydgenote was. Sy metafisika is egter nie bloot ' $n$ teologiese kantaantekening by 'n groter dialekties-filosofiese projek nie - in die nagloed van Eckhardt, is sy metafisika ook ten diepste met die mistieke teologie van die vyftiende eeu verweef. Gersonius (1363-1429) het in sy polemieke reeds 'n skerp onderskeid tussen die spekulatiewe teologie en die mistieke teologie getref. Die spekulatiewe teologie is die resultaat van die intellektuele krag van die rasionele siel, terwyl die mistieke teologie die affektiewe krag van die rasionele siel is. Die mistieke teologie vooronderstel die liefde van God, morele deug en die strewe na die perfekte siel en is daarom nie net vir die teologie nie, maar vir alle gelowiges toeganklik. Die spekulatiewe teologie vooronderstel studie en 'n skerp intellek en is daarom nie vir almal toeganklik nie.

Kusa eksponeer hierdie onderskeid tussen die spekulatiewe en mistieke teologie met sy unieke opvattinge van docta ignorantia [gestudeerde onkunde] en die via negativa [die negerende weg]. Trouens, Kusa bring die mistieke en spekulatiewe teologie ineens dialekties bymekaar. In sy De docta ignorantia (ca.1440; Kusa 1981) word hierdie dialektiese styl baie duidelik na vore gebring. In dié werk eksploreer Kusa aanvanklik die simbiose of minstens interpenetrasie van geloof en rede.

Met ' $\mathrm{n}$ standpunt wat duidelik aan Dionisius eeue vantevore herinner, postuleer Kusa (1981:11): 'Geloof omvou alles verstaanbaar en verstaan is die oopvou van geloof'. Hy bespreek verder in dié werk die Goddelike oneindigheid, kosmiese onbepaalbaarheid en - daartussen - menslike begrensdheid op dialekties-spekulatief-mistiese wyse. Die mens is trouens vir Kusa die skakel tussen die Goddelike oneindigheid en kosmiese onbepaalbaarheid, synde gesitueer op die horison tussen tyd en ewigheid. Tussen mens en God staan uiteindelik net taal, in die begrensdheid daarvan. Kusa maak ruim gebruik van metafore, maar die ontologie determineer die metafore - die metafore determineer nie die ontologie nie (Kusa 1983:56). Daarby dring Kusa aan op 'n spekulatiewe verbeelding wat God en mens in terme van God se konneksie met die skepping analogies verwoord (vgl. Miller 2017: Afd 4).

Kusa (1981:13) se definisie van ewigheid is op die oog af uniek: die 'absolute maksimum en Een'. Die absolute maksimum is alles en alles daarin. Dit is egter ook 'Een': niks kan by die ewigheid gevoeg of daaruit weggelaat word nie. Die absolute maksimum betrek alles by implikasie: God impliseer alle dinge in die sin dat alle dinge in God is, maar God ekspliseer ook alle dinge in die sin dat God in alle 
dinge is. Die 'absolute maksimum' beteken vir Kusa (1981:17) daarom beweging wat die eksplisering van die rustende toestand is, en dit impliseer tyd, wat die eksplisering van ewigheid is. Tyd is 'n geordende teenswoordigheid. Die teenswoordige is nou, die verlede was teenswoordig en die toekoms sal teenswoordig wees. Tydelike wesens neem aan die oneindigheid deel, want daarsonder sou geen bestaan moontlik wees nie.

Die oneindige transendeer egter die eindige orde, wat uit opposisies, verskille en teenoorstellinge bestaan. Die oneindige daarenteen is die perfekte koïnsidensie van verskil en opposisie (coincedentia oppositorum; Kusa 1981:27). Die heelal is in alles op 'n saamgetrekte wyse en alles trek in sigself die heelal saam. Al hierdie oorwegings dui op 'n skerp dialektiese aanvoeling en die vasberade poging om spekulatiewe en mistieke teologie te verenig.

By al die dialektiese oorspronklikheid daarvan, het Kusa se metafisika destyds egter ernstige voorbehoude opgeroep. Sy standpunt dat God alle dinge is (Deus est omnia) het vir die filosofies-ondergeskoolde leser duidelik na panteïsme geneig. Trouens, reeds in die 1440's het Johannes Wenck, professor in teologie aan die Universiteit van Heidelberg, 'n filosofies-suspisieuse dog fel kritiek op De docta ignorantia gepubliseer (vgl. Luscombe 1997:178). Die kerklikakademiese instemming op die kritiek was van so 'n aard dat Kusa geen ander keuse gehad het as om 'n apologie op die werk te skryf nie (Apologiae doctae ignorantiae, 1449). In die apologie verdedig Kusa die dialektiese kwaliteit van sy werk, maar herformuleer hy ook talle sentrale stellinge in die werk, wat baie van die kreatiewe impetus van die oorspronklike werk ondermyn het. Verder sou daar uit die kader van die mistieke teologie self hewige reaksie wees. Vincent van Aggsbach, 'n Carthusiaanse ab in die tradisie van Ekchardt, ontken dat die spekulatiewe rede hoegenaamd die mistieke teologie kan penetreer. Indien die spekulatiewe rede dit sou kon doen, sou mistieke teologie juis nie kon bestaan nie. Aggsbach argumenteer ook dat Kusa hom aan talle oorsigte skuldig gemaak het. Hy wys veral op die feit dat Kusa die eenvoudige unie tussen God en mens op grond van God se liefde en genade probeer dialektiseer, en dat dit nie met die wesenlike eenvoud van die mistieke teologie te versoen is nie (vgl. Beukes 2012:17).

Tog het Kusa getrou gebly aan sy konkordansie. Hy argumenteer dat duidelike opposisies soos geloof en rede, of natuur en genade, in konkordansie gebring moet word. Daarsonder is daar 'geen toekoms of verlede nie' (Kusa 1981:42). Aggsbach sien opposisies - Kusa soek konkordansie midde die opposisies. Dit herinner aan 'n sonderlinge, ontwykende stem, 900 jaar vóór Kusa.

\section{Die Dionisiese spoor in Kusa se metafisika}

In hierdie gedeelte sal teen die agtergrond van die voorafgaande artikel (Beukes 2018) en die afdelings supra, aangedui word dat daar inderdaad Dionisiese spore in Kusa se metafisika aanwesig is, en wel ten opsigte van die volgende sewe 'spore' (S):

S1: Die interpretasie van die transendente as van-langs die immanente.

S2: Die affirmering van God se transendensie in die wêreld, skepping as differensiasie, in daardie sin as 'teofanie', oftewel 'n metafisika van die 'skepping as teofanie', ontleen aan Perl (2007) se analise.

S3: Die radikale transendensie en tegelyk radikale immanensie van God, oftewel 'God as Synheid'.

S4: Fundamentele taalbegrensdheid in die spreke oor God en die analogiese 'be-Naming' van God.

S5: Die skepping as 'n stelsel van dialektiese simbole oor God, oftewel proto-semiotiek.

S6: Die analogiese deelname van die subjek aan die skepping.

S7: Unifikasie, oftewel die terugvloei van alle dinge na God.

In De li non aliud, soos hierbo bespreek, keer Kusa (1983) duidelik terug na antieke Platoniese, Middel-Platoniese en Neoplatoniese kategorieë rondom die 'Een' en die 'Ander' (vgl. Collins 1999:4). Wanneer Kusa (1983:7-12) 'n dialektiek uitwerk van God wat die aardse transendeer en tog terselfdertyd immanent daarin teenwoordig is (immanent, in die sin dat God nie anders is as enige ding nie; transendent, in die sin dat God ongekwalifiseerd nie-ander is), is dit 'n eksplisiete bevestiging van S1, S2 en S3. Wanneer Kusa (1981:111) postuleer dat 'geloof omvou alles verstaanbaar en verstaan is die oopvou van geloof', koppel dit bykans verbatim terug na Dionisius: 'God is die toevouer van alle dinge en alle dinge is die oopvouer van God'. ${ }^{9}$

Wanneer Kusa aantoon dat God alle onderskeide wat mense kan maak, transendeer, in die sin dat God anders is as die heelal, maar, dialekties, in die heelal self God 'nie-anders' as die heelal is, bevestig Kusa onteenseglik dit wat Dionisius met die 'Synheid van God' bedoel (S3): synde die Synheid van alle Syndes en nie hoogste Syn nie, alleen 'kenbaar' deur die 'Name' in begrensde Syndes of skepsels, kan God alleen deur simbole geken word. In Kusa se taal (1983:15): God transendeer elke kategorie omdat God absoluut 'nie-ander' is (S3); tegelyk transendent en immanent.

Groot afdelings in beide Dionisius (vgl. Copleston 1993:91; Perl 2007) en Kusa (Casarella 2008:667; vgl. Martin 1996:212) se oeuvres fokus gevolglik op analogie en die skepping as 'n stelsel van tekens en beide oeuvres is in daardie sin 'protosemioties'. Dit geld ook vir die betekende kategorie van taal, wat tegelyk grammatikaal begrensd en analogies onbegrensd is, maar terselfdertyd oomblik vir oomblik diskursief verruim moet word. Kusa is duidelik oortuig van die taalbegrensdheid van die subjek en die aangewesenheid op analogie (vgl. O'Rourke 1992:143). Wanneer Kusa stel dat daar tussen mens en God uiteindelik 'net taal staan' - juis in die begrensdheid daarvan, maar terselfdertyd 'n metaforiek ontwikkel waar ontologie die metafore determineer, en die metafore nie die ontologie determineer nie - is dit duidelik 'n bevestiging van 9.Pseudo-Dionisius (1990:De Divinis Nominibus 1.7,597A). 
die skepping as 'n stelsel van dialektiese simbole oor God en die deelname van die subjek aan die skepping as intrinsiek analogies (S4, S5 \& S6).

Slegs God kan oor Godself in nie-analogiese terme praat. Analogie en metaforisiteit is 'geskenke' (Kusa 1983:8) waarmee nie 'n soort verbeeldingryke oorspronklikheid vanuit die subjek opgeroep word nie, maar waarmee die subjek juis herinner word dat daar geen proporsie tussen Skepper en skepping bestaan nie; dat Skepper en skepping trouens asimmetries is. Tog ontstaan 'n simmetrie met God as 'nie-ander' wanneer die subjek telkens en opnuut weer ander metafore in die begrensde taalhandeling (moet) kies; juis daar waar God as 'Anders' binne talige skopus 'nie-ander' word; transendensie nie van bo of onder nie, maar van-langs (reds. Christianson \& Izbicki 1991:3).

Simbole bring God tot uitdrukking, maar is nie God self of iets van Godself nie. Die simbool bring God voor die gesig en laat God dadelik agter, die simbool ontbloot en hersluier - en maak God op hierdie wyse kenbaar sonder om God tot Syn te objektiveer. In beide Dionisius en Kusa se taal: alleen in 'n simbool kan God ontmoet word sonder dat God se ontoeganklikheid ondermyn word, en daarom kan die ware Goddelikheid van God - as Synheid van alle Syndes en nie hoogste Syn nie - slegs in simboliek verwoord word. God is nie (Nie)-Ander nie, maar nie-ander (red. Armstrong 1967:524).

Wanneer Dionisius Neoplatonies stel ${ }^{10}$ dat soos wat die siel opstyg vanaf sintuiglike waarneming na diskursiewe rede na intellektualisering, die bevatlikheid daarvan tot 'n groterwordende eenheidsgreep toeneem tot daar waar intellektuele kennis oorgaan in die stilte van eminensie en dat dit die siel se hoogste, weliswaar 'mistieke' unifikasie met God, in nie-kennende stilte is, is dit tematies digby Kusa se 'absolute maksimum en Een'. Trouens, daar is tussen Dionisius en Kusa op hierdie punt geen verskil nie: die unifikasie met God is nie teenoorstaande die verstand of intellek se kognitiewe funksies nie, maar die hoogste doel en uitdrukking daarvan. Daar is ook geen opposisie tussen sintuig en intellek nie, omdat beide intellek en sintuig hoër en laer modi van dieselfde kennende aktiwiteit is, naamlik die bevatlikheid tot 'n eenheidsgreep op die werklikheid (S7). Kusa se definisie van ewigheid, die 'absolute maksimum en Een', is dus net op die oog af uniek. Dit is onmiskenbaar ontleen aan Neoplatonisme en aan Dionisius in die besonder. Vir Kusa is die absolute maksimum 'alles en alles daarin'. Dit is egter ook en steeds 'Een': Niks kan by die ewigheid gevoeg of daaruit weggelaat word nie. Tussen Kusa se Een en Dionisius se Een, is daar bykans woordeliks geen verskil nie (S7).

'Negatiewe teologie' beteken vir Dionisius, soos sy Neoplatoniese voorgangers, nie ongekontroleerde negasie

10.Pseudo-Dionisius (1990:De Divinis Nominibus VII 2869C). Die lente van verwysings per Harvard na die primêre tekste van Pseudo-Dionisius (1990) werk
steurend in op die vloei van die teks. Daarom word verwysings na die primêre steurend in op die vloei van die teks. Daarom word verwysings na die primêre tekste van Pseudo-Dionisius per voetnote hanteer. nie, maar juis gekontroleerde, gedissiplineerde 'stilte' en 'stilwording'; om die 'verskuildheid van die Goddelike, anderkant verstand en Syn' met 'n 'gewyde en daarom wyse stilte' te eerbiedig (reds. Bosley \& Tweedale 2004:535, 547-555). ${ }^{11}$ Eenheid, gelykheid en unie dui insgelyks, volgens Kusa (1983:15), die on-onderskeid van die subjek se blik op God self aan, die dus ongedifferensieerde aard van God se Syn en tegelyk God se 'nie-andersheid'. Elke konkordansie bestaan immers volgens Kusa (1991:7) uit verskille, en hoe minder opposisie daar tussen die verskille is, hoe groter die konkordansie. Hierdie konkordansie presenteer vir hom dus die eerste beginsel, of God. Daar is uiteindelik tussen die dinamika van Dionisius se stillerwordende hiërargie en Kusa se stilsoekende konkordansie geen verskil nie: beide is gemoeid met reditus, die mistiese, stilwordende terugvloei van alle dinge na God (S7).

Spore 1 tot 7 dui aan tot welke mate Kusa se metafisika konseptueel aansluiting vind by Dionisius. Kusa het volledig toegang gehad tot die negende-eeuse vertaling van die Corpus Dionysiacum. Dit was voorhande en hy het dit gebruik tot die bestendiging van sy eie spekulatief-mistiese dialektiek, soos Eriugena, Aquinas en Eckhardt voor hom. Nie een van hierdie drie Middeleeuse denkers se metafisika was konseptueel egter so verbonde aan spesifiek Dionisius as juis Kusa nie. Dat die 'poortwag van die moderne' hom so sou ingrawe in en hom konseptueel so sou verlaat het op die nalatenskap van 'n ontwykende Bisantynse monnik vanuit die sesde eeu, ${ }^{12}$ kan beskryf word as 'n merkwaardige en produktiewe palimpses vanuit die korpus van die laatMiddeleeuse filosofie. Miskien is juis daarin vir laatmoderniteit ook iets ten opvatting van herwinning te leer (red. Bocken 2002:3).

Trouens, is dit nie juis wat 'diskursiewe herinnering' (Beukes 2005:1104) kan beteken nie - om temperend en versigtig te vra na verwaarloosde en vergete momente uit die geestesgeskiedenis; momente wat, indien dit subtiel herwin of herwaardeer word, 'n geproblematiseerde eietydse konteks van nuwe impetus kan voorsien? Soos wat Kusa die hulp van 'n antieke voorvader ingeroep het om 'n metafisiese posisie te verhelder, selfs te konstrueer, kan ons nie goedskiks die hulp van ons voorgangers inroep, wat inderdaad deur die moderne vernietiging van die metafisika verdaag is, om 'n 'eietydse metafisika' te verhelder nie veral wanneer dit gaan oor die laat-moderne fragmentering van wesenlike begrippe in die Westerse filosofie; begrippe wat juis nie wegstaan van metafisika nie? Is dit nie juis die wins aan, byvoorbeeld, Goosen (2017:585-586) se uiters belangrike en insiggewende herlesing van Perl, wat Dionisius op sy beurt grondig herlees het nie (Perl 2007); om daarmee te bevestig dat 'ons menswees ten nouste met metafisiese vraagstelling verweef is' (Goosen 2017:584)?

\section{Pseudo-Dionisius (1990:De Divinis Nominibus IV.20,720B).}

12.Eco het in The Name of The Rose gesuggereer: By ' $n$ monnik hoort sardonie en skalkse humor slegs in ' $n$ laaste voetnota. Kusa self was langs sy tydgenoot Lorenzo Valla die vyftiende-eeuse eksegeet wat opnuut Dionisius se 'ware' identiteit Valla die vyftiende-eeuse eksegeet wat opnuut Dionisius se 'ware' identiteit
bevraagteken het, met detail-analises en kruisverwysings vanuit Proklus na bevraagteken het, met detail-analises en kruisverwysings vanuit Proklus na
Dionisius (vgl. Beierwaltes 1977; Casarella 2008; Duclow 2002). 
Moet ons nie $\mathrm{Eco}^{13}$ se ander advies volg en ons 'voorvadere' gereeld besoek nie, as 'n 'immunologiese voorsorg' teen veral die gefragmenteerde eietydse opvattinge rondom Self en Ander, identiteit en nie-identiteit, geregtigheid en gemeenskap (Colish 1999:4)?

Is Kusa se herkonstruering van Dionisius, as 'n diskursiewe herinnering meer as 900 jaar voor hom, maar ook nou weer reeds ' $n$ diskursiewe herinnering meer as 500 jaar ná hom juis op grond van die duidelik nie-progressiewe en eerder 'spekulatiewe' aard daarvan, nie 'n voorbeeldige geleier wat ons nog altyd weer voor die spanningsvolle ruimtes tussen 'vorm' en 'afgrond', 'woord' en 'stilte', 'begrip' en 'misterie' kan laat vertoef nie (Beukes 2011:1)? Is dit dalk uit daardie metafisiese opflikkering moontlik om selfs in die filosofies-verarmde, epistemologies-gebroke een-entwintigste eeu - juis met 'n opgeskerpte sin vir patos - te kan verwys na die Een wat deur die 'tradisie op 'n gepaste wyse as die onbeskryflik Goeie, Een of God' beskryf is (Goosen 2017:585)?

Dalk is juis dit te neem uit die Dionisiese spore in Kusa se metafisika: dat daardie patos altyd weer, bo die volgende verstaanshorison uit, 'n aanspraak sal rig. Of die patos opstygend as 'metafisies' benoem word of nie maak immers geen verskil aan die afstygende Een self nie. Transendent, soos wat die Een is, is dit moontlik om die Een simbolies en kontemplatief-liturgies in die wêreld self te affirmeer - sonder om die Een nihilisties uit die wêreld te ban, of verwondering oor die Een as nostalgies en stilwording voor die Een se ewige stilte, as postuum te verklaar.

Ut enim monachōrum opera legerem, necesse erat mē ipsum monachum fierī.

\section{Literatuurverwysings Mededingende belange}

Die outeur verklaar dat hy geen finansiële of persoonlike verbintenis het met enige party wat hom nadelig kon beïnloed het in die skryf van hierdie artikel nie.

\section{Literatuurverwysings}

Albertson, D., 2008, 'Mapping the space of God: Mystical Weltbilder in Nicholas of Cusa and the structure of De ludo globi (1463)', in P. Billion (red.), Weltbilder im Mittelalter: Perceptions of the world in the middle ages, pp. 61-81, Bernstein, Bonn.

Albertson, D., 2010, 'Mystical philosophy in the fifteenth century: New directions in research on Nicholas of Cusa', Religion Compass 4(8), 471-485. https://doi. org/10.1111/j.1749-8171.2010.00232.x

Anoniem, n.d., Nicolaus Cusanus, Meister des Marienlebens, ca.1463-ca.1490, viewed n.d., from https://de.wikipedia.org/wiki/Datei:Nicholas_of_Cusa.jpg

13.'It would hardly be a waste of time if sometimes even the most advanced students in the cognitive sciences were to pay a visit to their ancestors. It is frequently claimed in philosophy departments that, in order to be a philosopher, it is not necessary to revisit the history of philosophy. It is like the claim that one can become a painter without having ever seen a single work by Raphael, or a writer without having ever read the classics. Such things are theoretically possible; but the without having ever read the classics. Such things are theoretically possible; but the
"primitive" artist, condemned to an ignorance of the past, is always recognisable as such and rightly labeled as naï. It is only when we consider past projects revealed as utopian or as failures that we are apprised of the dangers and possibilities for failure for our allegedly new projects. The study of the deeds of our ancestors is thus more than an antiquarian pastime, it is an immunological precaution (Eco 1997:5)
Armstrong, A.H. (red.), 1967, The Cambridge history of later Greek and early Medieval philosophy, Cambridge University Press, Cambridge.

Beierwaltes, W., 1977, Identität und Differenz: Zum Prinzip cusanischen Denkens, Rheinisch-Westfälische Akademie der Wissenschaften, Westdeutscher, Opladen.

Beierwaltes, W., 1985, Denken des Einen, Klostermann, Frankfurt am Main.

Beierwaltes, W., 1997, Der verborgene Gott: Cusanus und Dionysius, Paulinus, Trier.

Bertelloni, F., 2006, 'Marsilius of Padua', in J.J.E. Gracia \& T.B. Noone (eds.), A companion to philosophy in the middle ages, pp. 413-420, Blackwell, Oxford.

Beukes, J., 2005, 'Terreur, roes en ordes: Die monnik as blywende simbool van erns in die filosofie', HTS Teologiese Studies/Theological Studies 61, 1101-1129. https:// doi.org/10.4102/hts.v61i4.474

Beukes, J., 2011, 'God kan net doen wat God wel doen: Petrus Abelardus se Megariaanse argument in Theologia Scholarium, Opera Theologia III', HTS Teologiese Studies/Theological Studies 67(1), Art. \#124, besigtig 18 Mei 2018, vanaf https://doi.org/10.4102/hts.v67i1.124

Beukes, J., 2012, 'Vanaf Ockham na Kusa: Die ensiklopediese aanspraak van 'n postskolastiek in die Middeleeuse filosofie', HTS Teologiese Studies/Theological Studies 68(1), Art. \#2381, besigtig 14 Mei 2018, https://doi.org/10.4102/hts. v68i1.1134

Beukes, J., 2018, "n Herlesing van Pseudo-Dionisius se metafisika', HTS Teologiese Studies/Theological Studies 74(4), Art. \#5111.

Bocken, I. (red.), 2002, On cultural ontology: Religion, philosophy and culture, Uitgeverij Shaker, Maastricht.

Bosley, R.N. \& Tweedale, M. (reds.), 2004, Basic issues in medieval philosophy. Selected readings presenting the interactive discourses among the major figures, Broadview Press, Ontario.

Casarella, P.J., 2008, 'Cusanus on Dionysius: The turn to speculative theology', ModernTheology24,667-678.https://doi.org/10.1111/j.1468-0025.2008.00492.x

Christianson, G. \& Izbicki, T. (reds.), 1991, Nicholas of Cusa: In search of God and wisdom, Brill, Leiden.

Collins, R., 1999, Early Medieval Europe 300-1000, St Martin's Press, New York.

Colish, M.L., 1999, Medieval foundations of the Western intellectual tradition, Yale University Press, New Haven, CT.

Copleston, F.C., 1972, A history of Medieval philosophy, Methuen, Londen.

Copleston, F.C., 1993, A history of philosophy Volume II, Medieval philosophy, Doubleday, New York.

Duclow, D.F., 2002, Nicholas of Cusa's conjectural Neoplatonism, in I. Bocken (red.), On cultural ontology: Religion, philosophy and culture, pp. 71-87, Uitgeverij Shaker, Maastricht.

Dupre, L. \& Hudson, N., 2006, 'Nicholas of Cusa', in J.J.E. Gracia \& T.B. Noone (reds.), A companion to philosophy in the middle ages, pp. 466-474, Blackwell, Oxford.

Eco, U., 1997, The search for the perfect language, J. Fentress (vert.), Blackwell, Oxford.

Flasch, K., 1966, Die Metaphysik des Einen bei Nikolaus von Kues, Brill, Leiden.

Gewirth, A., 1979, 'Republicanism and absolutism in the thought of Marsilius of Padua', Medioevo 5, 23-48.

Goosen, D., 2017, 'Die metafisiese tradisie vandag. 'n Interpretasie van Eric D. Perl', Litnet Akademies 14(3), 557-591.

Hannam, J., 2009, God's philosophers: How the medieval World Laid the foundations of modern science, Icon Books, Londen.

Haren, M., 1985, Medieval thought. The Western intellectual tradition from antiquity to the thirteenth century, Macmillan, Londen.

Hathaway, R.F., 1969, Hierarchy and the definition of order in the letters of PseudoDionysius, Nijhoff, Den Haag.

Hopkins, J., 1978, A concise introduction to the philosophy of Nicholas of Cusa, University of Minnesota Press, Minneapolis, MN.

Hopkins, J., (vert., red. en komm.), 1981, Nicholas of Cusa, on learned ignorance: A translation and an appraisal of 'De docta ignorantia', University of Minnesota Press, Minneapolis, MN.

Hopkins, J., (vert., red. en komm.), 1983, Nicholas of Cusa, on God as not-other: A translation and an appraisal of 'De li non aliud', University of Minnesota Press, Minneapolis, MN

Hopkins, J., (vert., red. en komm.), 1985, Nicholas of Cusa's dialectial mysticism: Text, translation and interpretive study of 'De visione dei', Banning Minneapolis, MN.

Hopkins, J., 2001, (vert.). Complete philosophical and theological treatises of Nicholas of Cusa, Banning, Minneapolis, MN.

Hyman, A., Walsh, J.J. \& Williams, T. (reds.), 2010, Philosophy in the middle ages: The Christian, Islamic and Jewish traditions, Hackett, Indianapolis, IN.

Klibansky, R., 1981, The continuity of the Platonic tradition during the middle ages, Kraus, Munchen.

Koterski, J.W., 2009, An introduction to Medieval philosophy: Basic concepts, WileyBlackwell, Sussex.

Kusa, N.V., 1932-2007, Opera Omnia jussu et auctoritate Academicae Litterarum Heidelbergensis, Meiner, Leipzig-Hamburg.

Kusa, N.V., 1981, De docta ignorantia, Hopkins (vert., red. \& komm.), University of Minnesota Press, Minneapolis, MN. 
Kusa, N.V., 1983, De li non aliud, Hopkins (vert., red. \& komm.), University of Minnesota Press, Minneapolis, MN.

Kusa, N.V., 1985, De visione dei, Hopkins (vert., red. \& komm.), Banning, Minneapolis, MN.

Kusa, N.V., 1991, De concordantia catholica II, Sigmund (vert.), Cambridge University Press, Cambridge.

Luscombe, D.E., 1997, Medieval thought, Oxford University Press, Oxford.

Marenbon, J., 1988, Early Medieval philosophy (488-1150). An introduction, Routledge, New York.

Martin, C.J.F., 1996, An introduction to Medieval philosophy, Edinburgh University Press, Edinburgh.

Miller, C.L., 2017, 'Cusanus, Nicolaus [Nicolaus of Cusa]', in E.N. Zalta (red.), The Stanford encyclopedia of philosophy, viewed 14 May 2018, from https://plato. stanford.edu/archives/sum2017/entries/cusanus

Moran, D., 2007, 'Nicholas of Cusa and modern philosophy', in J. Hankins (red.), The cambridge companion to renaissance philosophy, pp. 173-192, Cambridge University Press, Cambridge.

Munz, P., 1960, 'The thirteenth century and the ideas of Marsilius of Padua', Historical Studies 9, 156-172. https://doi.org/10.1080/10314616008595163
O'Rourke, F., 1992, Pseudo-Dionysius and the metaphysics of Aquinas, Brill, Leiden. Padua, M., 1932, Defensor Pacis, R. Scholz (red.), Hahn, Hanover.

Pasnau, R. \& Van Dyke, C. (reds.), 2010, The Cambridge history of Medieval philosophy Volume I, Cambridge University Press, Cambridge.

Perl, E.D., 2006, 'Pseudo-Dionysius', in J.J.E. Gracia \& T.B. Noone (reds.), A companion to philosophy in the middle ages, pp. 540-549, Blackwell, Oxford.

Perl, E.D., 2007, Theophany: The Neoplatonic philosophy of Dionysius the Areopagite, State University of New York Press, Albany, NY.

Pseudo-Dionisius, 1988, Pseudo-Dionysius: The complete works, Luibheid, C. (vert.) Rorem, M. (vert.), Froehlich, K. (inl.). Paulist Press, NJ.

Pseudo-Dionisius, 1990, Corpus Dionysiacum, B.R. Suchla, G. Heil en A.M. Ritter (reds.), De Gruyter, Berlyn.

Sigmund, P.E., 1963, Nicholas of Cusa and Medieval political thought, Harvard University Press, Cambridge.

Sigmund, P.E. (vert.). 1991, Nicholas of Cusa: The Catholic concordance, Cambridge University Press, Cambridge.

Wyller, E., 1970, 'Zum Begriff Non Aliud bei Cusanus', in Nicolò Cusano agli Inizi del Mondo Moderno, pp. 419-443, Sansoni, Florence. 